\title{
Prediksi Risiko Perubahan Perilaku Nasabah Asuransi Berbasis Matriks Stokastik dan Model INAR(1) Poisson
}

\author{
Dwi Haryanto ${ }^{1}$, Khreshna I. A. Syuhada ${ }^{2}$ \\ ${ }^{1}$ Aktuaria, FMIPA, Institut Teknologi Bandung, haryantodwi2011@gmail.com \\ ${ }^{2}$ KK Statistika, FMIPA, Institut Teknologi Bandung, khreshna@math.itb.ac.id
}

\begin{abstract}
Abstrak
Salah satu risiko yang mungkin dialami perusahaan asuransi adalah menurunnya pendapatan yang bersumber dari premi nasabah. Penurunan pendapatan tersebut karena frekuensi nasabah yang keluar lebih besar daripada frekuensi nasabah yang baru masuk (mendaftar). Oleh karena itu, perlu dilakukan kontrol terhadap pola perubahan perilaku nasabah untuk meminimalisir risiko. Pada artikel ini, dilakukan prediksi risiko dari suatu produk asuransi yaitu prediksi frekuensi pembayaran premi yang telah dilakukan nasabah atau selanjutnya disebut sebagai prediksi waktu atas loyalitas nasabah dan prediksi atas kemungkinan berkurangnya frekuensi nasabah. Prediksi waktu atas loyalitas nasabah dikonstruksi dengan menggunakan matriks stokastik. Sementara, prediksi atas kemungkinan berkurangnya frekuensi nasabah yang merupakan agregat dari frekuensi nasabah yang mengundurkan diri dan meninggal dunia, dikonstruksi dengan menggunakan model integer valued firstorder autoregressive (INAR(1)) yang inovasinya berdistribusi Poisson. Hasil yang diperoleh adalah perusahaan asuransi perlu memberikan perlakuan khusus terhadap nasabah-nasabah yang telah mencapai jangka waktu tertentu. Hal ini bertujuan untuk menjaga loyalitas nasabah agar risiko yang diakibatkan karena berkurangnya frekuensi nasabah dapat diminimalisir.
\end{abstract}

Kata kunci: prediksi risiko, asuransi, matriks stokastik, model INAR(1) Poisson

\begin{abstract}
One of the risks that might occur in insurance companies is the decrease in income from customer premiums. The decrease in income is due to the frequency of coming out customers is greater than the frequency of new customers (registering). Therefore, it is necessary to control the pattern of changes in customer behavior to minimize risk. In this article, a prediction of the risk of an insurance product is made, namely the prediction of the frequency of premium payments made by a customer or hereinafter referred to as a time prediction of customer loyalty and prediction of the possibility of decreasing customer frequency. Prediction of time of customer loyalty is constructed using stochastic matrices. Meanwhile, prediction of the possibility of reduced customer frequency is constructed using integer valued first-order autoregressive (INAR(1)) model with Poisson innovation. The result obtained is insurance companies need to provide special treatment to customers who have reached a certain period of premium payments. This is intended to maintain customer loyalty so that the risk from reduced customer frequency can be minimized.

Keywords: risk prediction, insurance, stochastic matrix, INAR(1) Poisson model
\end{abstract}

2000 Mathematics Subject Classification:

Received: 2019-08-31, Revisions: 2020-01-19; Accept : 2020-01-30. 


\section{Pendahuluan}

Pada industri asuransi, salah satu risiko yang mungkin terjadi adalah menurunnya pendapatan perusahaan yang diakibatkan nasabah memilih berpindah atau keluar dari produk asuransi yang sedang diikutinya [1]. Risiko ini tentu saja akan berpengaruh terhadap keseimbangan keuangan perusahaan, karena di sisi yang lain perusahaan juga harus melakukan pembayaran secara berkala terhadap klaim yang diajukan nasabah. Oleh karena itu, perusahaan perlu melakukan kontrol terhadap pola perubahan perilaku nasabah untuk meminimalisir risiko.

Salah satu kontrol yang dapat dilakukan perusahaan asuransi adalah memprediksi waktu atas loyalitas nasabah. Loyalitas nasabah merupakan suatu faktor yang signifikan dalam kesuksesan bisnis asuransi [2]. Loyalitas nasabah dapat juga diartikan sebagai karakter psikologis yang dibentuk oleh kepuasan yang berkelanjutan dari nasabah ditambah dengan ikatakan emosional yang terbentuk dengan perusahaan [3]. Perhatian terhadap loyalitas nasabah menjadi salah satu faktor yang penting dalam strategi pemasaran yang bertujuan untuk mempertahankan nasabah dan mengembangkan hubungan lebih lanjut antara nasabah dan perusahaan [4].

Prediksi waktu atas loyalitas nasabah dapat dilakukan dengan mengetahui pola perubahan perilaku nasabah secara umum dari suatu produk asuransi. Perilaku nasabah yang dibahas dalam artikel ini adalah perilaku nasabah dengan status kepesertaan aktif dan tidak aktif. Dalam jangka waktu kedepan, perubahan perilaku nasabah dapat terjadi dari status kepesertaan aktif menjadi tidak aktif. Menurut Mathur dan Tripathi [5], ada beberapa faktor yang mempengaruhi nasabah dalam memilih perusahaan asuransi diantaranya lokasi, layanan dan infrastruktur perusahaan, keamanan data, teknologi, reputasi dan lain sebagainya. Sehingga sangat dimungkinkan nasabah untuk beralih dari satu perusahaan ke perusahaan yang lain. Sementara itu, perubahan perilaku lain yang mungkin dialami nasabah adalah perubahan dari kondisi belum memiliki asuransi menjadi merasa tertarik untuk bergabung pada produk asuransi tertentu. Dalam kasus ini, terjadi perubahan status kepesertaan tidak aktif menjadi aktif.

Perubahan perilaku nasabah yang berpindah dari satu kategori ke kategori lain dapat dinyatakan ke dalam model rantai Markov. Taylor dan Karlin [6] menjelaskan bahwa peluang perubahan perilaku ke perilaku yang lain dari model rantai Markov hanya dipengaruhi oleh perilaku saat ini dan tidak dipengaruhi oleh perilaku pada masa lalu. Sementara itu, Hunter [7] menjelaskan bahwa ekspektasi banyaknya periode waktu yang telah dilalui nasabah untuk merubah perilakunya dapat ditentukan dengan memanfaatkan besarnya peluang perpindahan dari satu perilaku ke perilaku yang lain. Hal tersebut kemudian dikaitkan dengan teori tentang waktu kunjungan pertama kali dari suatu rantai Markov. Selanjutnya, besarnya peluang perpindahan dari satu perilaku ke perilaku yang lain dapat direpresentasikan ke dalam matriks stokastik untuk memudahkan dalam perhitungan. Mempertimbangkan hal tersebut, pada artikel ini dikonstruksi matriks stokastik dari suatu rantai Markov atas perubahan perilaku nasabah dari suatu produk asuransi.

Setelah mengetahui prediksi waktu atas loyalitas nasabah, hal lain yang juga dikaji dalam artikel ini adalah melakukan prediksi atas kemungkinan berkurangnya frekuensi nasabah. Tujuannya adalah untuk mengetahui besarnya pengurangan pendapatan yang akan terjadi sehingga pihak perusahaan dapat dengan tepat menentukan target yang harus dipenuhi oleh bagian pemasaran (marketing) dalam merekrut nasabah baru. Terdapat dua hal yang dapat menyebabkan frekuensi nasabah berkurang yaitu agregat dari frekuensi nasabah yang mengundurkan diri dan nasabah yang meninggal dunia. Berkenaan dengan hal tersebut, model risiko agregat yang sesuai untuk melakukan prediksi atas berkurangnya frekuensi nasabah adalah

$$
S_{2}=X_{1}+X_{2}
$$

dengan $S_{2}$ merupakan peubah acak dari frekuensi nasabah yang keluar yang merupakan agregat dari $X_{1}$ yaitu peubah acak dari frekuensi nasabah yang mengundurkan diri dan $X_{2}$ yaitu peubah acak dari frekuensi nasabah yang meninggal dunia. 
Dalam melakukan prediksi risiko agregat atas frekuensi nasabah yang keluar, peubah acak $X_{1}$ dan $X_{2}$ masing-masing dikonstruksi dari model Integer Valued Autoregressive berorde satu (INAR(1)) Poisson. Model INAR pertama kali diperkenalkan oleh Al-Osh dan Alzaid [8]. Model prediksi INAR(1) Poisson dari peubah acak $X_{1}$ pada artikel ini dipengaruhi oleh frekuensi nasabah yang mengundurkan diri pada waktu $t-1$ sampai $t$ dengan peluang mengundurkan diri sebesar $\alpha$ ditambah dengan suatu inovasi $\epsilon_{t}$ yang berdistribusi Poisson. Sedangkan model prediksi INAR(1) Poisson dari peubah acak $X_{2}$ dipengaruhi oleh frekuensi nasabah yang meninggal dunia pada waktu $t-1$ sampai $t$ dengan peluang meninggal dunia sebesar $\beta$ ditambah dengan suatu inovasi $\eta_{t}$ yang juga berdistribusi Poisson. Selanjutnya, hasil prediksi frekuensi nasabah yang mengundurkan diri dan meninggal dunia akan diagregatkan untuk mengetahui hasil prediksi frekuensi nasabah yang keluar dari suatu produk asuransi. .

\section{RANTAi MARKOV}

Pada bidang asuransi, perubahan perilaku nasabah harus dapat dimodelkan dengan tepat. Perubahan perilaku nasabah tersebut diamati untuk mengetahui strategi yang tepat dalam mengembangkan bisnis asuransi. Salah satu metode yang bisa digunakan untuk memodelkan perubahan perilaku nasabah adalah menggunakan model rantai Markov [9]. Pembahasan tentang perilaku nasabah tersebut dibagi ke dalam tiga bagian yaitu klasifikasi keadaan, waktu kunjungan pertama kali, dan funsi Kemeny.

2.1. Klasifikasi Keadaan. Misalkan $\left\{X_{n}, n \geq 0\right\}$ merupakan proses stokastik, dengan $X_{n}$ merupakan peubah acak yang menyatakan perilaku-perilaku atau keadaan-keadaan yang mungkin dialami nasabah dari suatu produk asuransi pada waktu $n$. Proses stokastik tersebut dikatakan sebagai rantai Markov jika untuk semua keadaan $i_{0}, i_{1}, \ldots, i_{n-1}, i, j$ memenuhi [6] [10]:

$$
P\left(X_{n+1}=j \mid X_{n}=i, \ldots, X_{1}=i_{1}, X_{0}=i_{0}\right)=P\left(X_{n+1}=j \mid X_{n}=i\right) .
$$

Pandang $\left\{X_{n}, n=0,1, \ldots, t\right\}$ merupakan rantai Markov yang merepresentasikan keadaan status kepesertaan nasabah aktif $\left(X_{n}=0\right)$ atau tidak aktif $\left(X_{n}=1\right)$ dari suatu produk asuransi pada waktu $n$. Distribusi peluang transisi dari keadaan tersebut ditentukan menggunakan parameter $\left(\alpha_{0}, \alpha_{1}\right)$. Oleh karena itu, matriks stokastik yang memenuhi kondisi tersebut adalah

$$
P=\left(\begin{array}{cc}
1-\alpha_{0} & \alpha_{0} \\
1-\alpha_{1} & \alpha_{1}
\end{array}\right)
$$

dengan ruang keadaan dari proses tersebut adalah $S=\{0,1\}$. Nilai $\alpha_{0}$ menunjukkan peluang nasabah yang sebelumnya memiliki status kepesertaan aktif menjadi tidak aktif. Sedangkan, nilai $\alpha_{1}$ menunjukkan peluang nasabah yang sebelumnya berstatus tidak aktif tetapi tidak tertarik untuk bergabung di asuransi tersebut sehingga statusnya tetap tidak aktif. Dengan kata lain kondisi tersebut dapat dinyatakan dalam persamaan (2).

$$
P\left(X_{n+1}=j \mid X_{n}=i\right)=(-1)^{1-j} \alpha_{i}+1-j .
$$

Selanjutnya, kasus yang digunakan dalam artikel ini adalah melakukan prediksi waktu atas loyalitas nasabah. Menentukan prediksi waktu atas loyalitas nasabah sama halnya dengan menentukan banyaknya langkah yang dibutuhkan seorang nasabah untuk berpindah dari keadaan aktif ke keadaan tidak aktif. Proses perhitungan prediksi waktu atas loyalitas nasabah tersebut dapat dilakukan dengan menggunakan teori waktu kunjungan pertama kali dan fungsi Kemeny, di mana kedua teori tersebut berkaitan dengan distribusi stasioner dari rantai Markov.

Definisi 2.1. [6] Misalkan $\mathbf{P}=\left[P_{i j}\right]$ merupakan matriks peluang transisi $(m+1$ keadaan $)$ dari suatu rantai Markov dan misalkan terdapat $\boldsymbol{\pi}=\left[\pi_{0}, \pi_{1}, \ldots, \pi_{m}\right]^{T}$ sedemikian sehingga $\pi_{j}=\sum_{i=0}^{m} \pi_{i} P_{i j}$ dengan $\sum_{j=0}^{m} \pi_{j}=1$ maka $\pi$ adalah distribusi stasioner dari rantai Markov.

Berdasarkan definisi dari distribusi stasioner, maka tidak semua rantai Markov memiliki fungsi Kemeny. Menurut Hunter [7] distribusi stasioner ( $\boldsymbol{\pi}$ ) dari rantai Markov dapat diperoleh hanya untuk rantai Markov yang tidak dapat direduksi. Oleh karena itu untuk rantai Markov dengan kondisi seperti yang ditunjukkan dalam persamaan (2), syarat yang harus dipenuhi agar 
rantai Markov tersebut tidak dapat direduksi adalah memiliki nilai $\alpha_{0}$ dan $\alpha_{1}$ yang memenuhi kondisi seperti yang tercantum dalam Tabel ??.

TABEL 1. Syarat Rantai Markov Dua Keadaan Tidak Dapat Direduksi

\begin{tabular}{lc}
\hline \hline$\alpha_{0}$ & $\alpha_{1}$ \\
\hline $0<\alpha_{0}<1$ & $0<\alpha_{1}<1$ \\
$0<\alpha_{0}<1$ & 0 \\
1 & $0<\alpha_{1}<1$ \\
1 & 0 \\
\hline \hline
\end{tabular}

Sementara itu, untuk beberapa rantai Markov dengan kasus khusus, distribusi stasioner dari rantai Markov dengan dua ruang keadaan tidak dapat ditentukan. Beberapa rantai Markov dengan kasus khusus tersebut memiliki nilai $\alpha_{0}$ dan $\alpha_{1}$ yang membuat matriks peluang transisinya menjadi bentuk khusus seperti yang termuat dalam Tabel 2 .

TABEL 2. Syarat Rantai Markov Dua Keadaan Dapat Direduksi

\begin{tabular}{lcc}
\hline \hline$\alpha_{0}$ & $\alpha_{1}$ & Keterangan \\
\hline 0 & 0 & Matriks segitiga bawah \\
0 & 1 & Matriks identitas \\
0 & $0<\alpha_{1}<1$ & Matriks segitiga bawah \\
1 & 1 & Matriks segitiga atas \\
$0<\alpha_{0}<1$ & 1 & Matriks segitiga atas \\
\hline \hline
\end{tabular}

2.2. Waktu Kunjungan Pertama Kali. Ekspektasi waktu kunjungan pertama kali $\left(m_{i j}\right)$ merupakan ekspektasi banyaknya transisi yang terjadi untuk mencapai keadaan $j$ yang pertama kali, bersyarat keadaan awal berada di keadaan $i$. Ekspektasi waktu kunjungan pertama kali ini digunakan dalam proses prediksi waktu atas loyalitas nasabah dengan memperhatikan matriks stokastik yang berisi peluang perpindahan antar keadaan.

Misalkan $N_{i j}$ merupakan peubah acak yang menyatakan banyaknya transisi yang terjadi dari keadaan awal $i$ untuk mencapai keadaan $j$ pertama kali dari suatu rantai Markov. $N_{i j}$ dapat ditentukan dengan persamaan 3 .

$$
N_{i j}=\min \left\{n \geq 1: X_{n}=j \mid X_{0}=i\right\} .
$$

Selanjutnya, menurut Kemeny dan Snell [11] $m_{i j}$ dapat diperoleh melalui proses pada persamaan 4.

$$
m_{i j}=E\left(N_{i j} \mid X_{0}=i\right)=1+\sum_{k \in S, k \neq j} p_{i k} m_{k j}
$$

Dari persamaan (4), misalkan $\mathbf{M}=\left[m_{i j}\right], \mathbf{M}_{d}=\operatorname{diag}\left(m_{00}, \ldots, m_{m m}\right)$, dan $\mathbf{E}=[1]=\mathbf{e e}^{T}$ diperoleh $\mathbf{M}=\mathbf{E}+\mathbf{P}\left(\mathbf{M}-\mathbf{M}_{d}\right)$, dengan ruang keadaan dari $X_{n}$ adalah $S=\{0,1,2, \ldots, m\}$ dan $\mathbf{e}^{T}=(1,1, \ldots, 1)$. Kemudian, dari persamaan $\mathbf{M}=\mathbf{E}+\mathbf{P}\left(\mathbf{M}-\mathbf{M}_{d}\right)$, jika kedua ruas dikalikan dengan $\boldsymbol{\pi}^{T}$ maka diperoleh $\boldsymbol{\pi}^{T} \mathbf{M}_{d}=\boldsymbol{\pi}^{T} \mathbf{E}$. Karena $\boldsymbol{\pi}^{T}=\left[\pi_{0}, \pi_{1}, \ldots, \pi_{m}\right]$ dan $\sum_{j=0}^{m} \pi_{j}$ menghasilkan $\boldsymbol{\pi}^{T} \mathbf{M}_{d}=\mathbf{e}^{T}$ sehingga $m_{j j}=1 / \pi_{j}$.

2.3. Fungsi Kemeny. Fungsi Kemeny merupakan suatu fungsi yang digunakan untuk memprediksi banyaknya transisi dari suatu keadaan ke keadaan lain dari suatu rantai Markov, di mana keadaan-keadaan tersebut telah mencapai kondisi yang stasioner. Misalkan $k_{i}$ menyatakan fungsi Kemeny dari suatu keadaan awal $i$ ke keadaan tujuan yang bersifat acak dari suatu rantai Markov. Menurut Hunter [7] fungsi Kemeny untuk rantai Markov $\left\{X_{n}, n=0,1, \ldots, t\right\}$ 
dengan ruang keadaan $S=\{0,1, . ., m\}$ dan matriks peluang transisi $\mathbf{P}$ dapat diperoleh dengan menggunakan persamaan 5 .

$$
k_{i}=\sum_{j=0}^{m} m_{i j} \pi_{j} .
$$

Selanjutnya, jika $\mathbf{k}^{T}=\left(k_{0}, k_{1}, \ldots, k_{m}\right)$ maka persamaan (5) dapat dinyatakan sebagai

$$
\mathbf{k}=\mathbf{M} \pi \text {. }
$$

Kemudian, menggunakan persamaan $m_{j j}=1 / \pi_{j}$, fungsi Kemeny dari persamaan (6) dapat dibentuk ke dalam suatu matriks yang semua unsur-unsurnya bernilai 0 seperti pada persamaan 7 .

$$
(\mathbf{I}-\mathbf{P}) \mathbf{k}=(\mathbf{I}-\mathbf{P}) \mathbf{M} \boldsymbol{\pi}=\mathbf{e e}^{T} \boldsymbol{\pi}-\mathbf{P e}=\mathbf{e}-\mathbf{e}=\mathbf{0}
$$

Jika diperhatikan lebih lanjut maka persamaan (7) merupakan vektor eigen kanan dari matriks $\mathbf{P}$. Dengan demikian dari persamaan (7) diperoleh $\mathbf{k}=k \mathbf{e}$ untuk beberapa konstanta $k$, mengakibatkan $k_{i}=k$ untuk setiap $i$. Oleh karena itu, fungsi Kemeny atau yang biasa dinotasikan dengan $K_{C}$ merupakan suatu konstanta untuk semua $i$. Hal tersebut mengakibatkan keadaan awal dari suatu rantai Markov tidak mempengaruhi ke keadaan yang ingin dicapai.

\section{Model Prediksi INAR(1) Poisson}

3.1. Model INAR(1) Poisson. Model INAR(1) Poisson didefinisikan sebagai berikut.

Definisi 3.1. [12] Model INAR(1) Poisson didefinisikan oleh

$$
X_{t}=\alpha \circ X_{t-1}+\epsilon_{t}, t=0, \pm 1, \pm 2, \ldots
$$

dengan $\alpha \circ X_{t-1}$ saling bebas dengan $\epsilon_{t}, \epsilon_{t}$ merupakan peubah acak yang saling bebas dan berdistribusi identik Poisson. Untuk $\alpha \in[0,1)$, operator ' ${ }^{\prime}$ ' yang disebut sebagai binomial thinning didefinisikan oleh

$$
\alpha \circ X_{t-1}=\sum_{i=1}^{X_{t-1}} W_{i}
$$

dengan $W_{i} \sim \operatorname{Bern}(\alpha)$

Distribusi dari $X_{t}$ dapat ditentukan dengan menggunakan teknik fungsi pembangkit peluang dan sifat discrete self-decomposable [13]. Misalkan untuk $\epsilon_{t} \sim \operatorname{Poi}(\lambda)$ maka $X_{t} \sim$ Poi $\left(\frac{\lambda}{1-\alpha}\right)$. Sementara itu, distribusi dari $\alpha \circ X_{t-1}$ juga dapat ditentukan dengan menggunakan fungsi pembangkit peluang. Misalkan untuk $X_{t-1} \sim \operatorname{Poi}(\lambda)$ maka $\alpha \circ X_{t-1} \sim \operatorname{Poi}(\alpha \lambda)$. Oleh karena itu, pada distribusi Poisson, operator binomial thinning bersifat mengawetkan distribusi. Hal tersebut karena operator binomial thinning tidak mempengaruhi jenis distribusinya hanya saja mempengaruhi mean dari distribusi Poisson. Untuk lebih jelasnya, berikut ini ditampilkan pada Gambar 1, ilustrasi pengaruh operator binomial thinning dalam hal ini terhadap fungsi peluangnya

Selanjutnya, pada artikel ini dilakukan kajian tentang sifat-sifat statistik dari model INAR(1) Poisson. Sifat-sifat statistik yang dikaji yaitu ekspektasi, variansi, dan fungsi pembangkit momen (tidak) bersyarat dari $X_{t}$. Ekspektasi dan variansi bersyarat digunakan dalam proses penentuan parameter yang akan ditaksir. Menurut Freeland [14], ekspektasi, variansi, dan momen (tidak) bersyarat dari $X_{t}$ dapat ditentukan dengan menggunakan proses rekursif dari model INAR(1) berikut

$$
X_{t}=\alpha \circ X_{t-1}+\epsilon_{t}=\alpha^{k} \circ X_{t-k}+\sum_{j=0}^{k-1} \alpha^{j} \circ \epsilon_{t-j} .
$$

Diperoleh hasil ekspektasi, variansi, dan fungsi pembangkit momen (tidak) bersyarat dari $X_{t}$ seperti yang termuat dalam Tabel 3 berikut. 


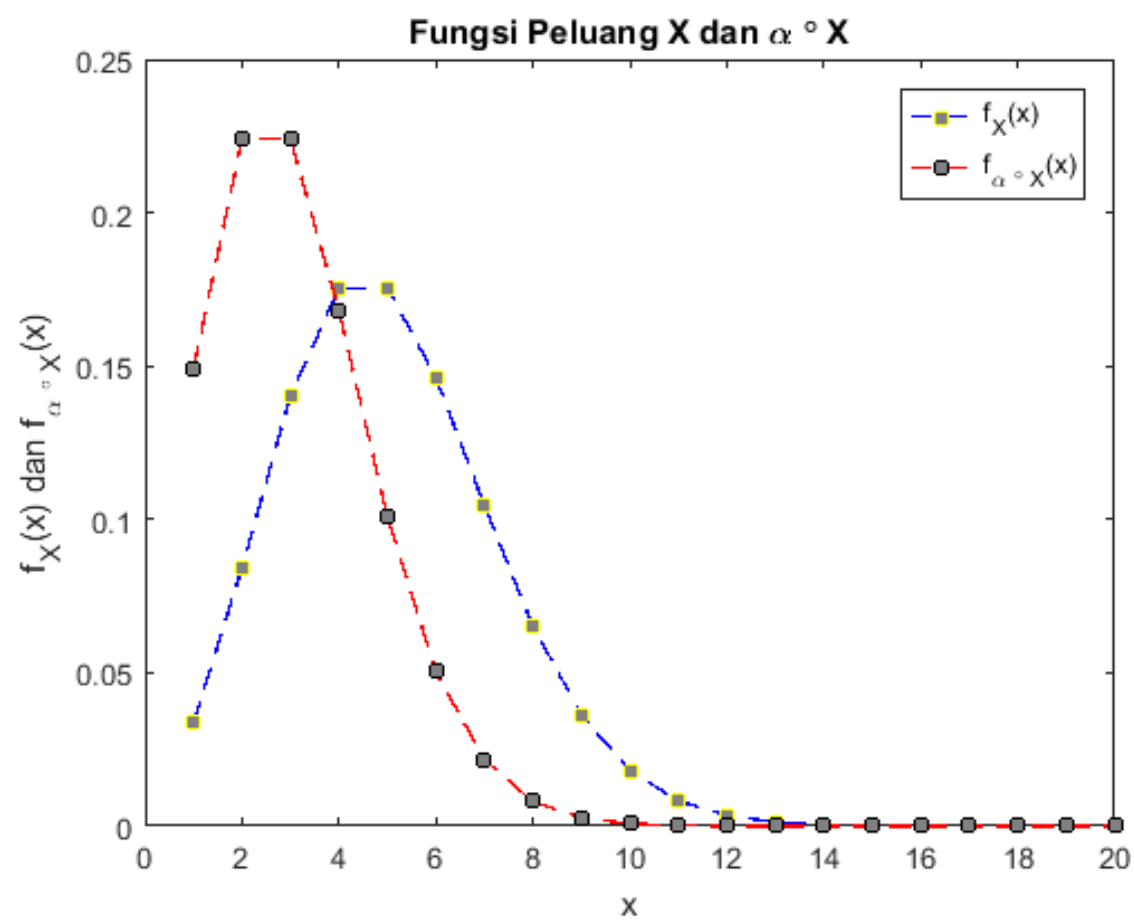

Gambar 1. Fungsi Peluang $X \sim \operatorname{Poi}(\lambda)$ dan $\alpha \circ X \sim \operatorname{Poi}(\alpha \lambda)$

TABel 3. Ekspektasi, Variansi, dan Fungsi Pembangkit Momen (tidak) Bersyarat dari $X_{t}$

\begin{tabular}{ccc}
\hline \hline$E_{X_{t}}, \operatorname{Var}_{X_{t}}, M_{X_{t}}$ & $k=1$ & $k \rightarrow \infty$ \\
\hline$E\left[X_{t} \mid X_{t-k}\right]$ & $\alpha x_{t-1}+\lambda$ & $\frac{\lambda}{1-\alpha}$ \\
$E\left[X_{t}\right]$ & $\alpha E\left[X_{t-1}\right]+\lambda$ & $\frac{\lambda}{1-\alpha}$ \\
$\operatorname{Var}\left[X_{t} \mid X_{t-k}\right]$ & $\alpha(1-\alpha) x_{t-1}+\lambda$ & $\frac{\lambda}{1-\alpha}$ \\
$\operatorname{Var}\left[X_{t}\right]$ & $\alpha^{2} \operatorname{Var}\left[X_{t-1}\right]+\alpha(1-\alpha) E\left[X_{t-1}\right]+\lambda$ & $\frac{\lambda}{1-\alpha}$ \\
$M_{X_{t} \mid X_{t-k}}(s)$ & $\left(\alpha e^{s}+(1-\alpha)\right)^{X_{t-1}} e^{\lambda\left(e^{s}-1\right)}$ & $e^{\frac{\lambda}{1-\alpha}\left(e^{s}-1\right)}$ \\
$M_{X_{t}}(s)$ & $e^{\lambda\left(e^{s}-1\right)} E\left[\left(\alpha e^{s}+(1-\alpha)\right)^{X_{t-1}}\right]$ & $e^{\frac{\lambda}{1-\alpha}\left(e^{s}-1\right)}$ \\
\hline \hline
\end{tabular}

Jika diperhatikan dari ekspektasi, variansi, ataupun fungsi pembangkit momen (tidak) bersyarat, maka distribusi dari $X_{t} \mid X_{t-k}$ sama dengan $X_{t}$ yaitu berdistribusi Poisson $\left(\frac{\lambda}{1-\alpha}\right)$. Pada Gambar 2 disajikan ilustrasi pengaruh beberapa nilai $\alpha$ terhadap fungsi pembangkit momen.

3.2. Model INAR(1) Poisson pada Risiko Agregat. Misalkan $R$ menyatakan banyaknya penyebab yang mengakibatkan nasabah keluar dari asuransi dan $X_{i, t}$ merupakan peubah acak yang menyatakan banyaknya nasabah yang keluar dari produk asuransi pada waktu $t$ karena penyebab ke- $i$. Oleh karena itu, model risiko agregat banyaknya nasabah yang keluar dari asuransi pada waktu $t$ dapat dinyatakan sebagai

$$
S_{R, t}=X_{1, t}+X_{2, t}+\ldots+X_{R, t}
$$

dengan $R$ dapat bersifat stokastik atau deterministik. Selanjutnya, pada artikel ini dipilih model risiko agregat atas frekuensi nasabah yang keluar dari asuransi dikonstruksi dari agregat frekuensi nasabah yang mengundurkan diri dan frekuensi nasabah yang meninggal dunia. 


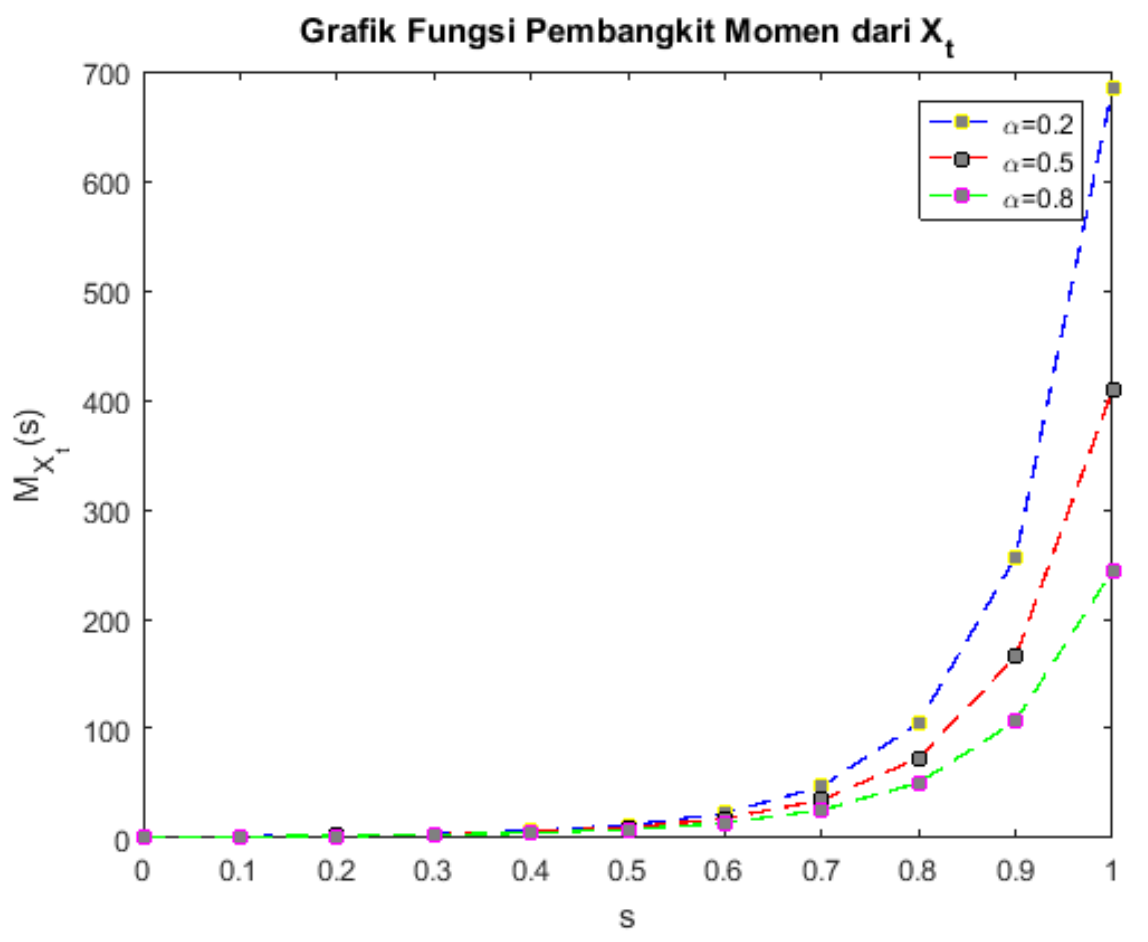

Gambar 2. Fungsi Pembangkit Momen $X_{t}$ dengan nilai $\alpha$ sebesar $0.2,0.5$, dan 0.8

Sehingga model risiko agregat yang sesuai dengan model tersebut adalah untuk $R=2$ sebagai berikut

$$
S_{2, t}=X_{1, t}+X_{2, t}
$$

dengan $X_{1, t}$ dan $X_{2, t}$ masing-masing dikonstruksi dari model INAR(1) Poisson sebagai berikut

$$
\begin{aligned}
& X_{1, t}=\alpha \circ X_{1, t-1}+\epsilon_{t} \\
& X_{2, t}=\beta \circ X_{2, t-1}+\eta_{t}
\end{aligned}
$$

di mana $\alpha, \beta \in[0,1)$. Peubah acak $X_{1, t}$ menyatakan frekuensi nasabah yang keluar dari asuransi dikarenakan mengundurkan diri. Frekuensi nasabah yang mengundurkan diri pada waktu $t$ dipengaruhi oleh frekuensi nasabah yang mengundurkan diri pada waktu $(\mathrm{t}-1, \mathrm{t}]$ dengan peluang $\alpha$ ditambah dengan $\epsilon_{t}$ yang selanjutnya disebut sebagai suatu inovasi yang terjadi pada waktu $t$. Sementara itu, peubah acak $X_{2, t}$ menyatakan frekuensi nasabah yang keluar dari asuransi karena nasabah yang bersangkutan meninggal dunia. Frekuensi nasabah yang meninggal dunia pada waktu $t$ merupakan penjumlahan dari frekuensi nasabah yang meninggal pada waktu (t-1,t] dengan peluang $\beta$ ditambah dengan suatu inovasi $\eta_{t}$.

Selanjutnya, pada artikel ini dikaji sifat statistik dari $S_{2, t}$. Sifat statistik yang dikaji adalah ekspektasi (tidak) bersyarat dan variansi (tidak) bersyarat. Diperoleh hasilnya seperti yang termuat dalam Tabel 4.

TABEL 4. Ekspektasi dan Variansi (tidak) Bersyarat dari $S_{2, t}$

\begin{tabular}{cc}
\hline \hline$E_{S_{2, t}}, \operatorname{Var}_{S_{2, t}}$ & $k=1$ \\
\hline$E\left[S_{2, t} \mid S_{2, t-k}\right]$ & $\lambda_{1}+\lambda_{2}+\alpha\left(s_{2, t-1}-x_{2, t-1}\right)+\beta\left(s_{2, t-1}-x_{1, t-1}\right)$ \\
$E\left[S_{2, t}\right]$ & $\lambda_{1}+\lambda_{2}+\alpha E\left[X_{1, t-1} \mid S_{2, t-1}\right]+\beta E\left[X_{2, t-1} \mid S_{2, t-1}\right)$ \\
$\operatorname{Var}\left[S_{2, t} \mid X_{2, t-k}\right]$ & $\lambda_{1}+\lambda_{2}+\alpha(1-\alpha)\left(s_{2, t-1}-x_{2, t-1}\right)+\beta(1-\beta)\left(s_{2, t-1}-x_{1, t-1}\right)$ \\
$\operatorname{Var}\left[S_{2, t}\right]$ & $\lambda_{1}+\lambda_{2}+\alpha(1-\alpha) E\left[X_{1, t-1} \mid S_{2, t-1}\right]+\beta(1-\beta) E\left[X_{2, t-1} \mid S_{2, t-1}\right]$ \\
\hline \hline
\end{tabular}


Kemudian untuk $k \rightarrow \infty$ diperoleh $E\left[S_{2, t} \mid S_{2, t-k}\right]=E\left[S_{2, t}\right]=\operatorname{Var}\left[S_{2, t} \mid X_{2, t-k}\right]$ $=\operatorname{Var}\left[S_{2, t}\right]=\frac{\lambda_{1}}{1-\alpha}+\frac{\lambda_{2}}{1-\beta}$. Sehingga dapat disimpulkan bahwa distribusi dari $S_{2, t} \mid S_{2, t-k}$ adalah sama dengan distribusi dari $S_{2, t}$ yaitu berdistribusi Poisson dengan mean sebesar $\left(\frac{\lambda_{1}}{1-\alpha}+\frac{\lambda_{2}}{1-\beta}\right)$.

\section{Hasil dan Pembahasan}

4.1. Prediksi Risiko Asuransi Berbasis Matriks Stokastik. Prediksi yang akan dibahas dengan menggunakan matriks stokastik adalah prediksi waktu atas loyalitas nasabah. Dalam praktiknya tentu saja nasabah memiliki kemungkinan untuk keluar yang dapat disebabkan oleh faktor internal atau faktor eksternal. Salah satu faktor internal yang mungkin dialami nasabah adalah adanya perubahan kondisi ekonomi yang menyebabkan nasabah tidak mampu membayar premi. Sementara itu faktor eksternal merupakan faktor yang diakibatkan dari pengalaman nasabah dalam mengikuti asuransi seperti kemudahan pembayaran premi, kemudahan dalam pengajuan klaim, dan lain sebagainya. Berikut ini merupakan matriks stokastik dari keadaan tersebut

$$
\mathbf{P}=\left(\begin{array}{cc}
1-\alpha_{0} & \alpha_{0} \\
1-\alpha_{1} & \alpha_{1}
\end{array}\right)
$$

dengan ruang keadaan $S=\{0,1\}$. Keadaan "0" menyatakan keadaan nasabah yang status kepesertaannya aktif sedangkan "1" menyatakan keadaan nasabah yang status kepesertaannya tidak aktif. Selanjutnya, dengan menggunakan persamaan (4) diperoleh ekspektasi dari waktu kunjungan pertama kali dari matriks stokastik tersebut adalah $m_{00}=\frac{1-\alpha_{1}+\alpha_{0}}{1-\alpha_{1}}, m_{10}=$ $\frac{1}{1-\alpha_{1}}, m_{01}=\frac{1}{\alpha_{0}}$, dan $m_{11}=\frac{1-\alpha_{1}+\alpha_{0}}{\alpha_{0}}$.

Pada artikel ini diasumsikan peluang nasabah untuk berpindah dari status kepesertaan aktif menjadi tidak aktif nilainya cukup kecil sehingga dipilih nilai $\alpha_{0}$ masing-masing sebesar $0.06,0.07,0.08,0,09,0.10$ dan 0.20 . Sedangkan peluang nasabah untuk tetap berada di status tidak aktif nilainya cukup besar, sehingga dipilih nilai $\alpha_{1}$ masing-masing sebesar $0.965,0.970,0.975,0.980,0.985$ dan 0.990 . Selanjutnya diperoleh taksiran parameter $\left(\widehat{\alpha_{0}}\right)$ dan $\left(\widehat{\alpha_{1}}\right)$ yaitu merupakan rata-rata dari data taksiran parameter dari data bangkitan pada masing-masing nasabah. Diperoleh, hasil prediksi banyaknya periode waktu yang telah dilalui nasabah $\left(\widehat{m_{01}}\right)$ sampai nasabah memutuskan untuk keluar dari asuransi tercantum dalam Tabel 5. Hasil prediksi yang lain yaitu banyaknya periode waktu yang telah dilalui nasabah sampai

TABel 5. Hasil Prediksi $\left(\widehat{m_{01}}\right)$

\begin{tabular}{ccc}
\hline \hline$\alpha_{0}$ & $\widehat{\alpha_{0}}$ & $\widehat{m_{01}}$ \\
\hline 0.06 & 0.058 & 17 \\
0.07 & 0.076 & 13 \\
0.08 & 0.082 & 12 \\
0.09 & 0.089 & 11 \\
0.10 & 0.105 & 9 \\
0.20 & 0.195 & 5 \\
\hline \hline
\end{tabular}

memutuskan untuk kembali bergabung ke asuransi $\left(\widehat{m_{10}}\right)$ tercantum dalam Tabel 6 .

Dari hasil pada Tabel (5) tersebut dapat dikatakan bahwa semakin kecil peluang nasabah untuk berpindah dari status aktif menjadi tidak aktif akan menyebabkan semakin besar banyaknya pembayaran premi yang telah dilakukan nasabah. Sementara itu, berdasarkan Tabel (6) dapat diperhatikan dari nilai $\widehat{m_{10}}$ menunjukkan bahwa besarnya peluang nasabah untuk tetap berada di status tidak aktif berbanding lurus dengan banyaknya tahapan yang telah dilewati nasabah sampai kemudian memutuskan untuk bergabung kembali di asuransi. Oleh karena itu berdasarkan hasil prediksi yang telah dilakukan, perusahaan perlu memberikan perlakuan khusus terhadap nasabah-nasabah yang sudah masuk ke dalam kategori memiliki kemungkinan 
TABEL 6. Hasil Prediksi $\left(\widehat{m_{10}}\right)$

\begin{tabular}{ccc}
\hline \hline$\alpha_{1}$ & $\widehat{\alpha_{1}}$ & $\widehat{m_{10}}$ \\
\hline 0.965 & 0.958 & 24 \\
0.970 & 0.962 & 27 \\
0.975 & 0.968 & 32 \\
0.980 & 0.972 & 36 \\
0.985 & 0.977 & 44 \\
0.990 & 0.981 & 53 \\
\hline \hline
\end{tabular}

untuk keluar. Seperti misalkan ketika nilai $\widehat{\alpha_{0}}=0.058$ maka ketika nasabah telah mencapai pembayaran ke 10 sampai 16 perusahaan dapat meminimalisir kemungkinan nasabah akan keluar dengan memberikan hadiah atau potongan harga premi khusus dengan syarat-syarat tertentu dengan tujuan menjaga loyalitas nasabah. Di sisi yang lain seperti hasil yang tercantum dalam Tabel 7 , ketika nilai $\widehat{\alpha_{1}}=0.958$, waktu yang dibutuhkan nasabah untuk tetap tidak tertarik bergabung di asuransi sebanyak 24 kali periode pembayaran premi.

Kemudian, ditinjau prediksi atas loyalitas nasabah dengan menggunakan fungsi Kemeny. Dengan menggunakan persamaan (5), diperoleh hasilnya seperti yang tercantum dalam Tabel 7. Dari Tabel (5) dan (7) dapat dilihat bahwa terjadi penurunan waktu atas loyalitas nasabah. Sementara itu, dari Tabel (6) dan (7) dapat dilihat juga terjadi penurunan waktu dari nasabah tidak aktif menjadi tertarik untuk bergabung di asuransi. Hal tersebut terjadi dengan syarat peluang nasabah untuk berpindah antar keadaannya telah mencapai kondisi yang stasioner.

4.2. Prediksi Berbasis Model INAR(1) Poisson. Pada model INAR(1) Poisson, persamaan $E\left[X_{t} \mid X_{t-1}=x_{t-1}\right]=\alpha x_{t-1}+\lambda=f\left(\theta, x_{t-1}\right)$ dengan $\theta=(\alpha, \lambda)$ merupakan parameter yang akan ditaksir. Pada artikel ini, merujuk kepada Thyregod, dkk [15] metode penaksiran parameter yang akan digunakan adalah metode Yule-Walker dan metode kuadrat terkecil.

TABEL 7. Hasil Prediksi $\left(\widehat{K_{C}}\right)$

\begin{tabular}{ccccc}
\hline \hline$\widehat{\alpha_{0}}$ & $\widehat{\alpha_{1}}$ & $\widehat{\pi_{0}}$ & $\widehat{\pi_{1}}$ & $\widehat{K_{C}}$ \\
\hline 0.058 & 0.958 & 0.42 & 0.58 & 11 \\
0.076 & 0.962 & 0.33 & 0.67 & 10 \\
0.082 & 0.968 & 0.28 & 0.72 & 10 \\
0.089 & 0.972 & 0.26 & 0.74 & 9 \\
0.105 & 0.977 & 0.18 & 0.82 & 8 \\
0.195 & 0.981 & 0.08 & 0.92 & 6 \\
\hline \hline
\end{tabular}

Penaksiran Parameter Metode Yule-Walker

Penaksiran parameter menggunakan metode Yule-Walker (Y-W) melibatkan kovariansi. Misalkan $\gamma(k)$ merupakan kovariansi pada lag ke $k$, diperoleh $\gamma(k)=\alpha^{k} \gamma(0)$. Oleh karena itu, penaksir $\alpha$ dengan menggunakan metode Yule-Walker adalah $\widehat{\alpha}=\frac{\gamma(1)}{\gamma(0)}$. Kemudian dengan mensubstitusikan $\gamma(1)$ dengan fungsi auto kovariansi sampel dan $\gamma(0)$ dengan variansi sampel maka penaksir $\alpha$ adalah

$$
\widehat{\alpha}=\frac{\sum_{t=0}^{n-1}\left(X_{t}-\bar{X}\right)\left(X_{t+1}-\bar{X}\right)}{\sum_{t=0}^{n}\left(X_{t}-\bar{X}\right)^{2}} .
$$

Selanjutnya, karena $\epsilon_{t} \sim \operatorname{Poi}(\lambda)$ maka penaksir $\lambda$ adalah

$$
\widehat{\lambda}=\frac{1}{n} \sum_{t=1}^{n} \widehat{\epsilon_{t}} \text {. }
$$


Penakisran Paramater Metode kuadrat terkecil

Penaksiran parameter $\alpha$ dan $\lambda$ dilakukan dengan meminimumkan persamaan

$$
S(\alpha, \lambda)=\sum_{t=1}^{n}\left(X_{t}-E\left[X_{t} \mid X_{t-1}\right]\right)^{2}=\sum_{t=1}^{n}\left(X_{t}-\alpha X_{t-1}-\lambda\right)^{2}
$$

Kemudian evaluasi persamaan (11) pada $\frac{\partial S}{\partial \alpha}=0$ dan $\frac{\partial S}{\partial \lambda}=0$, diperoleh

$$
\begin{gathered}
\widehat{\alpha}=\frac{\sum_{t=1}^{n} X_{t} X_{t-1}-\left(\sum_{t=1}^{n} X_{t} \sum_{t=1}^{n} X_{t-1}\right) / n}{\sum_{t=1}^{n} X_{t-1}^{2}-\left(\sum_{t=1}^{n} X_{t-1}\right)^{2} / n} \\
\widehat{\lambda}=\frac{1}{n}\left(\sum_{t=1}^{n} X_{t}-\widehat{\alpha} \sum_{t=1}^{n} X_{t-1}\right)
\end{gathered}
$$

Prediksi frekuensi nasabah yang mengundurkan diri

Pada artikel ini diasumsikan nilai awal dari banyaknya orang yang mengundurkan diri ada 49. Oleh karena itu dipilih nilai $\lambda_{1}=50$ yang artinya nilai tersebut masih berada di sekitaran asumsi nilai awal. Diperoleh hasil penaksiran parameter $\alpha$ dan $\lambda$ seperti yang tercantum dalam Tabel 8.

TABEL 8. Hasil Penaksiran Parameter $\widehat{\alpha}$ dan $\widehat{\lambda_{1}}$ untuk $n=1000$ Menggunakan Metode Yule-Walker dan Metode Kuadrat Terkecil

\begin{tabular}{ccccc}
\hline \hline \multirow{2}{*}{$\alpha$} & \multicolumn{2}{c}{$\widehat{\alpha}$} & \multicolumn{2}{c}{$\widehat{\lambda_{1}}$} \\
\cline { 3 - 6 } & $\mathrm{Y}-\mathrm{W}$ & $\mathrm{KT}$ & $\mathrm{Y}-\mathrm{W}$ & $\mathrm{KT}$ \\
\cline { 3 - 6 } 0.1 & 0.076 & 0.152 & 50.551 & 47.084 \\
0.3 & 0.334 & 0.363 & 46.745 & 45.195 \\
0.5 & 0.517 & 0.536 & 35.157 & 46.380 \\
0.7 & 0.709 & 0.761 & 49.797 & 39.904 \\
\hline \hline
\end{tabular}

Sementara itu hasil prediksi frekuensi nasabah yang mengundurkan diri untuk 1, 5, dan 10 langkah ke depan untuk $n=1000$ diperoleh hasilnya seperti yang termuat dalam Tabel 9 .

\begin{tabular}{|c|c|c|c|c|c|c|}
\hline \multirow{2}{*}{$\alpha$} & \multicolumn{2}{|c|}{$\widehat{X_{1, t+1}}$} & \multicolumn{2}{|c|}{$\widehat{X_{1, t+5}}$} & \multicolumn{2}{|c|}{$\widehat{X_{1, t+10}}$} \\
\hline & $\mathrm{Y}-\mathrm{W}$ & $\mathrm{KT}$ & Y-W & $\mathrm{KT}$ & $\mathrm{Y}-\mathrm{W}$ & $\mathrm{KT}$ \\
\hline 0.1 & 55 & 56 & 55 & 56 & 55 & 56 \\
\hline 0.3 & 71 & 70 & 70 & 71 & 70 & 71 \\
\hline 0.5 & 87 & 106 & 74 & 100 & 73 & 100 \\
\hline 0.7 & 158 & 152 & 168 & 162 & 171 & 165 \\
\hline
\end{tabular}

TABel 9. Hasil Prediksi $X_{1, t+1}, X_{1, t+5}$, dan $X_{1, t+10}$ untuk $n=1000$ Menggunakan Metode Yule-Walker dan Metode Kuadrat Terkecil

Prediksi frekuensi nasabah yang meninggal dunia

Pada artikel ini diasumsikan nilai awal frekuensi nasabah meninggal ada 26. Oleh karena itu dipilih nilai $\lambda_{2}=25$ yang artinya nilai tersebut masih berada di sekitaran asumsi nilai awal. Diperoleh hasil penaksiran parameter $\alpha$ dan $\lambda$ seperti yang tercantum dalam Tabel 10 .

Sementara itu hasil prediksi frekuensi nasabah yang meninggal dunia untuk 1, 5, dan 10 langkah ke depan untuk $n=1000$ diperoleh hasilnya seperti yang termuat dalam Tabel 11 . 
Tabel 10. Hasil Penaksiran Parameter $\widehat{\beta}$ dan $\widehat{\lambda_{2}}$ untuk $n=1000$ Menggunakan Metode Yule-Walker dan Metode Kuadrat Terkecil

\begin{tabular}{|c|c|c|c|c|}
\hline \multirow{2}{*}{$\beta$} & \multicolumn{2}{|c|}{$\widehat{\beta}$} & \multicolumn{2}{|c|}{$\widehat{\lambda_{2}}$} \\
\hline & Y-W & KT & Y-W & $\mathrm{KT}$ \\
\hline 0.1 & 0.121 & 0.141 & 24.867 & 23.971 \\
\hline 0.3 & 0.277 & 0.332 & 21.226 & 23.918 \\
\hline 0.5 & 0.469 & 0.538 & 25.693 & 22.960 \\
\hline 0.7 & 0.702 & 0.708 & 8.041 & 24.138 \\
\hline
\end{tabular}

TABel 11. Hasil Prediksi $X_{2, t+1}, X_{2, t+5}$, dan $X_{2, t+10}$ untuk $n=1000$ Menggunakan Metode Yule-Walker dan Metode Kuadrat Terkecil

\begin{tabular}{|c|c|c|c|c|c|c|}
\hline \multirow{2}{*}{$\beta$} & \multicolumn{2}{|c|}{$\widehat{X_{2, t+1}}$} & \multicolumn{2}{|c|}{$\widehat{X_{2, t+5}}$} & \multicolumn{2}{|c|}{$\widehat{X_{2, t+10}}$} \\
\hline & Y-W & KT & Y-W & KT & Y-W & KT \\
\hline 0.1 & 28 & 29 & 28 & 28 & 28 & 28 \\
\hline 0.3 & 32 & 35 & 29 & 36 & 29 & 36 \\
\hline 0.5 & 44 & 53 & 48 & 50 & 48 & 50 \\
\hline 0.7 & 82 & 77 & 40 & 81 & 29 & 83 \\
\hline 0.9 & 248 & 234 & 231 & 239 & 217 & 242 \\
\hline
\end{tabular}

\section{Prediksi frekuensi nasabah yang keluar}

Prediksi frekuensi nasabah yang keluar merupakan agregat dari frekuensi nasabah yang mengundurkan diri dan meninggal dunia dari suatu produk asuransi. Pada prediksi ini dipilih nilai $\lambda_{1}=50$ dan $\lambda_{2}=25$. Adapun hasil prediksi yang diperoleh untuk 1, 5, dan 10 langkah kedepan dengan kondisi $\alpha=\beta$ dan pengulangan $(n=1000)$ tercantum dalam Tabel 12.

TABeL 12. Prediksi Frekuensi Risiko Agregat dengan $\alpha=\beta$

\begin{tabular}{cccccccc}
\hline \multirow{2}{*}{$\alpha=\beta$} & \multicolumn{3}{c}{$\mathbf{Y}-\mathbf{W}$} & & \multicolumn{3}{c}{$\mathbf{K T}$} \\
\cline { 2 - 3 } \cline { 7 - 8 } & $\widehat{S_{2, t+1}}$ & $\widehat{S_{2, t+5}}$ & $\widehat{S_{2, t+10}}$ & $\widehat{S_{2, t+1}}$ & $\widehat{S_{2, t+5}}$ & $\widehat{S_{2, t+10}}$ \\
\hline $\mathbf{0 . 1}$ & 83 & 83 & 83 & & 85 & 84 & 84 \\
$\mathbf{0 . 3}$ & 103 & 99 & 99 & & 105 & 107 & 107 \\
$\mathbf{0 . 5}$ & 131 & 122 & 121 & & 159 & 150 & 150 \\
$\mathbf{0 . 7}$ & 240 & 208 & 200 & & 229 & 243 & 248 \\
$\mathbf{0 . 9}$ & 742 & 673 & 616 & & 711 & 723 & 731 \\
\hline
\end{tabular}

Dari Tabel (12) dapat dilihat bahwa ketika $\alpha$ dan $\beta$ semakin besar mengakibatkan semakin besarnya frekuensi nasabah yang keluar. Sementara itu, ketika nilai $\alpha$ dan $\beta$ lebih besar dari 0.5 menyebabkan hasil prediksi dengan menggunakan metode Y-W dan KT mengalami perbedaan yang cukup besar bila dibandingkan ketika nilai $\alpha$ dan $\beta$ kurang dari sama dengan 0.5. Kesimpulan yang sama juga berlaku berdasarkan Tabel (9) dan (11) semakin besar nilai $\alpha$ dan $\beta$ menyebabkan semakin besar frekuensi nasabah yang mengundurkan diri atau meninggal dunia dan juga menyebabkan perbedaan yang semakin besar hasil prediksi dengan menggunakan metode Y-W dan KT. Oleh karena itu, perusahaan harus dengan tepat membuat kebijakan atau strategi untuk menjaga loyalitas dari nasabah. 


\section{Simpulan}

Prediksi risiko asuransi yang dibahas dalam penelitian ini terdiri atas dua hal yaitu prediksi risiko atas frekuensi pembayaran premi yang telah dilakukan nasabah (loyalitas) sampai nasabah keluar dan prediksi risiko atas kemungkinan berkurangnya frekuensi nasabah dari suatu produk asuransi. Prediksi frekuensi pembayaran premi yang telah dilakukan nasabah sangat diperlukan oleh perusahaan asuransi sebagai acuan dalam menetapkan target yang harus dipenuhi oleh bagian pemasaran (marketing) dalam merekrut nasabah yang baru. Prediksi frekuensi pembayaran yang telah dilakukan nasabah akan sangat bergantung terhadap besarnya peluang perpindahan seorang nasabah dari keadaan aktif menjadi tidak aktif dari suatu matriks stokastik. Pada prediksi loyalitas nasabah ini, fungsi Kemeny dapat digunakan jika transisi antar keadaan dari matriks stokastik telah mencapai kondisi yang stasioner. Dari hasil analisis yang telah dilakukan menunjukkan bahwa semakin kecil peluang nasabah untuk berpindah dari status aktif menjadi tidak aktif akan menyebabkan semakin besar frekuensi pembayaran premi yang telah dilakukan nasabah.

Hasil analisis lain yang diperoleh adalah model INAR(1) Poisson dapat digunakan dalam memodelkan prediksi frekuensi nasabah yang keluar. Sementara itu, metode penaksiran parameter Yule-Walker dan Kuadrat Terkecil, keduanya dapat digunakan untuk menaksir parameter model INAR(1) Poisson. Prediksi frekuensi nasabah yang keluar dengan metode estimasi parameter Yule-Walker dan Kuadrat Terkecil memberikan hasil adanya perbedaan yang tidak terlalu signifikan ketika peluang nasabah yang meninggal dunia ataupun yang mengundurkan diri kurang dari 0.5. Sedangkan ketika peluang nasabah yang meninggal dunia ataupun yang mengundurkan diri lebih besar sama dengan 0.5 maka selisih hasil prediksi frekuensi nasabah yang keluar dengan metode penaksiran parameter Yule-Walker dan Kuadrat Terkecil hasilnya berbeda cukup signifikan.

\section{DAFTAR PUSTAKA}

[1] Guillen, M., Nielsen, J.P., dan Perez-Marin, A.M., 2008, The Need to Monitor Customer Loyalty and Business Risk in the European Insurance Industry, The Geneva Papers, 33, Pages 207-218.

[2] Mahmudi, R.K., dan Abdoli, E., 2016, The Effect of Service QUality on Customer Loyalty (Case Study: Clients of Asia Insurance Co., Miandoab, Iran), International Journal of Humanities and Cultural Studies, Volume 3 June, Pages 789-803.

[3] Rai, A.K., dan Medha, S., 2013, The Antecedents of Customer Loyalty: An Empirical Investigation in Life Insurance Context, Journal of Competitiveness, Volume 5, Issue 2, Pages 139-163.

[4] McMullan, R., dan Gilmore, A., 2008, Costumer Loyalty: An Empirical Study, European Journal of Marketing, Volume 42 No. 9/10, Pages 1084-1094.

[5] Mathur, D., dan Tripathi, A., 2014, Factors Influencing Customer's Choice For Insurance Companies- A Study of Ajmer City, IOSR Journal of Business and Management, Volume 16, 2, Pages 35-43.

[6] Taylor, H.M., dan Karlin, S., 1998, An Introduction to Stochastic Modeling Third Edition, Academic Press, New York.

[7] Hunter, J.J., 2018, Kemeny's Function for Markov Chains and Markov Renewal Processes, Linear Algebra and its Aplications, Volume 559, December 2018, Pages 54-72.

[8] Al-Osh, M.A., dan Alzaid, A.A., 1987, First Order Integer Valued Autoregressive (INAR(1)) Process, Journal of Time Series Analysis, Volume 8, Issue 3, Pages 261-275.

[9] Cheng, C.-J., Chiu, S.W., Cheng, C.-B., Wu, J.-Y., 2012, Customer Lifetime Value Prediction by A Markov Chain Based Data Mining Model: Application to An Auto Repair and Maintenance Company in Taiwan, Scientia Iranica, 19(3), Pages 849-855.

[10] Ross, S.M, 1996, Stochastic Processes Second Edition, John Wiley and Sons, Inc, USA.

[11] Kemeny, J.G., dan Snell, J.L., 1960, Finite Markov Chains, Springer-Verlag, New York.

[12] Al-Osh, M.A., dan Alzaid, A.A., 1988, First Order Integer Valued Autoregressive (INAR(1)) Process, Distributional and Regression Properties Statistica Neerlandica, Volume 42, Issue 1, Pages 53-61.

[13] Steutel, F.W., dan Harn, K.V., 1979, Discrete Analogues of Self-Decomposability and Stability, The Annals of Probability, Volume 7, No.5, Pages 893-899.

[14] Freeland, R.K., 1998, Statistical Analysis of Discrete Time Series with Aplication to the Analysis of Workers' Compensation Claims Data. PhD thesis, The Faculty of Graduate Studies Management Science Division, The University of British Columbia. 
[15] Thyregod, P., Carstensen, J., Madsen, H., dan Nielsen, K.A., 1999, Integer Valued Autoregressive Models for Tipping Bucket Rainfall Measurements, Environmetrics, Volume 10, December 1998, Pages 395-411. 
